\title{
PETROGRAPHY OF GLACIAL TILLS IN THE SZCZERCÓW OUTCROP, CENTRAL POLAND - PROBLEMS OF STRATIGRAPHIC INTERPRETATION
}

\author{
Dariusz Krzyszkowski $^{1}$, Lucyna Wachecka-Kotkowska ${ }^{2}$, Dariusz Wieczorek ${ }^{3}$, Andrzej Stoiński ${ }^{3}$ \\ ${ }^{1}$ University of Wroctaw, Institute of Geography and Regional Development, Pl. Uniwersytecki 1, \\ 50-137Wrocław, Poland; dariusz.krzyszkowski@ing.uni.wroc.pl \\ ${ }^{2}$ University of Łódź, Faculty of Geographical Sciences, Department of Geomorphology and Palaeogeography, \\ Narutowicza 88, 90-139 Łódź, Poland; lucyna.wachecka@geo.uni.lodz.pl \\ ${ }^{3}$ Geoconsult Sp. z o.o., Jurajska 6/40,25-640 Kielce, Poland; wieczorek@geoconsult.kie.pl; \\ stoinski@geoconsult.kie.pl
}

\begin{abstract}
The paper presents results of petrographic analyses of glacial tills in the western part of the Kleszczów Graben and the attempt of their stratigraphic interpretation. Petrographic coefficients have allowed the identification of five till lithotypes: T1, T2A, T2 and T2B - assigned to the South Polish Complex (Elsterian) and T4 correlated with the Middle Polish Complex (Saalian). The well-expressed tills that represent the South Polish Complex, occur at the bottom of the section. A new till lithotype, T2B, has been distinguished, corresponding to the Kuców Formation. It supplements the Pleistocene lithostratigraphic section of central Poland and corresponds to the Sanian 2 Glaciation. Among the younger tills, the T4 one (Odranian Glaciation) is well developed. The uppermost tills of the Wartanian cold stage have been reduced by glaciofluvial and fluvial erosion. It is, to some extent a consequence of the existence of a depression in this area, called the Szczerców Basin. The paper highlights the interpretational difficulties concerning the rank and the number of ice sheet advances during the Polish and Middle Polish Complexes in central Poland.
\end{abstract}

Key words: tills, petrography, lithostratigraphy, Pleistocene, central Poland, Kleszczów Graben.

Manuscript received 2 July 2015, accepted 10 November 2015

\section{INTRODUCTION}

Glacial till beds are of great importance for the Pleistocene lithostratigraphic schemes, because they constitute a direct evidence of glaciations. Therefore, the places such as two deep outcrops (Bełchatów and Szczerców) in the Bełchatów Open Cast Brown-Coal Mine, located in central Poland are of high significance (Fig. 1). They provide a relatively continuous sequence of sediments from the Neogene to the Holocene. These outcrops, separated by the Dębina Salt Diapir, are located in the Kleszczów Graben. The graben was covered a few times with Pleistocene Scandinavian ice sheets. It is manifested in the lithology of the section by accumulation of till beds. The last glacial episode, the Wartanian cold stage that terminated with deposition of the uppermost tills is correlated with MIS 6.

These areas are located in different geomorphological settings. The Szczerców outcrop (western part) is located in the Szczerców Basin (175-188 m a.s.1.). The upper geological layers are represented by the Vistulian fluvial and aeolian sediments and the Holocene fluvial-marshy deposits. Deeper in the section, there are Wartanian tills and glaciofluvial sands, examined in detail in the surrounding glacial plateau (outside the outcrop). The Bełchatów outcrop (eastern part) is located within the area of Bełchatów Plateau where the land elevations are approximately $190-238 \mathrm{~m}$ a.s.l. Glacial sediments are exposed at the surface, forming a glacial plateau locally cut by small valleys filled with Vistulian and Holocene deposits. Varying lithologies of the top Quaternary series over a short distance provoke the question whether we can expect a similar variation in the deeper parts of the basin.

Detailed lithostratigraphy for the Bełchatów outcrop was recognised in the early 1990s (see Krzyszkowski, 1992). It was subsequently verified and supplemented (see Allen and Krzyszkowski, 2008; Wachecka-Kotkowska et al., 2014). In the Szczerców vicinity, mining operations started in 2002 and the outcrop developed over a period of a few years. It created new opportunities to study Quaternary sediments. In 2008, 2010, 2012, 2013 and 2014 the authors undertook several research examinations in the Szczerców outcrop. Moreover, a map updating procedure was ongoing at that time on the Szczerców sheet (735) of the Detailed 


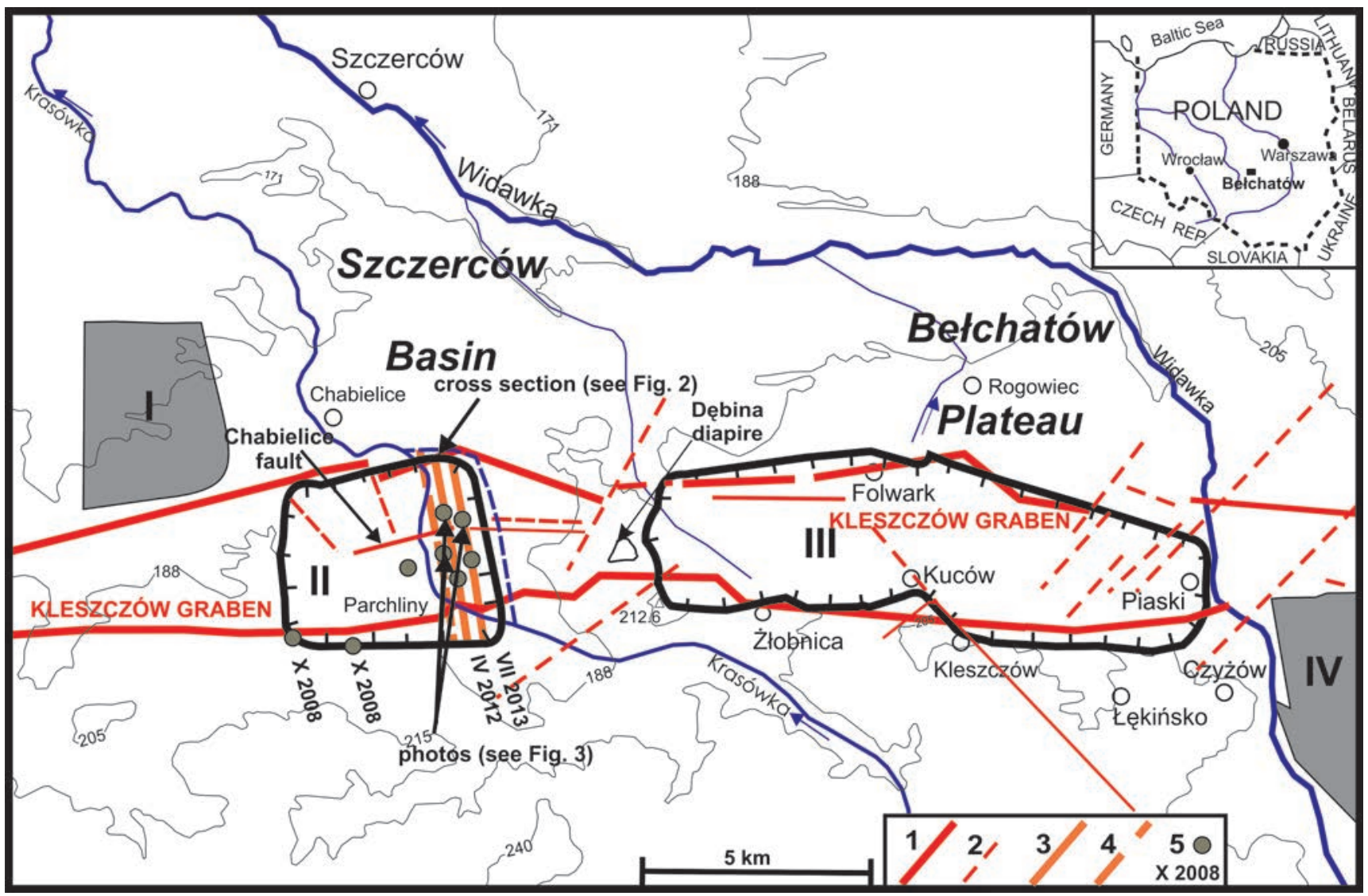

Fig. 1. Study area against the background of the KWB Bełchatów Coal Mine facilities. Faults, mainly in the sub-Cenozoic basement: $1-$ certain; 2 - presumable; 3 - first mining level; 4 - second mining level; 5 - place and time of sampling. Mining fields: II - Szczerców; III Bełchatów. Outer mine piles: I - Szczerców; IV - Kamieńsk.

Geological Map of Poland 1:50,000 (Wieczorek and Stoiński, 2013). The sheet encompasses the entire Szczerców outcrop (in the current size and in the final size). Other research teams also performed investigations in the outcrop (e.g. Król et al., 2007).

This paper presents the current results of petrographic analyses of glacial tills found in the Szczerców outcrop (western part of the Kleszczów Graben) and an attempt of their stratigraphic interpretation. Discussion of the research results has joined the currently ongoing debate on the Pleistocene stratigraphy of central Poland.

\section{RESEARCH HISTORY}

South Polish Complex and Middle Polish Complex are correlated with Elsterian and Saalian complexes in Western Europe, respectively (see Zagwijn, 1996; Ehlers and Gibbard, 2008; Marks, 2011).

In the Bełchatów outcrop, a special emphasis was put on the study of glacial tills of the Middle Polish Complex (Table 1). The Wartanian tills (Late Saalian, MIS 6) were analysed by Krzyszkowski (1988) and the Odranian tills (Early Saalian, MIS 6) by Czerwonka and Krzyszkowski (1990). Glacial tills of the South Polish Complex were studied too. Krzyszkowski (1992) and Czerwonka and Krzyszkowski (1992) studied petrographic coefficients of tills (Table 2). They have distinguished seven lithotypes of tills, starting from T1 (Folwark Formation from the Nidanian) and ending with tills marked as T7 (Rogowiec Formation from the Wartanian cold stage, see Table 1).

In the Szczerców outcrop, glacial tills were studied by Król et al. (2007), Wieczorek and Stoiński (2013), as well as by Wachecka-Kotkowska et al. (2013), Wieczorek et al. (in press) and Wachecka-Kotkowska et al. (2014).

Before the outcrop was excavated, tills from the Szczerców vicinity were described by Sarnacka (1970). Analyses of borehole sections and results of geological mapping suggested a presence of four tills (Sarnacka, 1971; Table 3). The two lowermost tills were considered to have been deposited during the glaciations in the South Polish Complex (Elsterian) - lower $\left(\mathrm{Q}^{1} \mathrm{p}_{2}\right)$ and upper $\left(\mathrm{Q}^{2} \mathrm{p}_{2}\right)$ stadials. The two upper tills come from the Middle Polish Glaciation - the maximum $\left(\mathrm{Q}^{1} \mathrm{p}_{3}\right)$ and the Wartanian stadial $\left(\mathrm{Q}^{2} \mathrm{p}_{3}\right)$ - present in the Middle Polish Complex (Saalian; see Table 3).

\section{TILL RESEARCH METHOD}

During field investigation, geological cross-sections were made (Fig. 2). Lithological, especially sedimentological studies were carried out in eight profiles (Fig. 1) located by the GPS receiver. Till samples were collected directly from walls at two exploitation levels (Fig. 3).

Petrographic analysis of gravels from the tills was performed on the $5-10 \mathrm{~mm}$ fraction, according to the standard specified by the Polish Geological Institute in Warsaw (Marks and Ber, 1999). A population of gravels (best $>300$ 
General Quaternary stratigraphy of the Kleszczów Graben according to Allen and Krzyszkowski (2008) and Wachecka-Kotkowska et al. (2014), modified

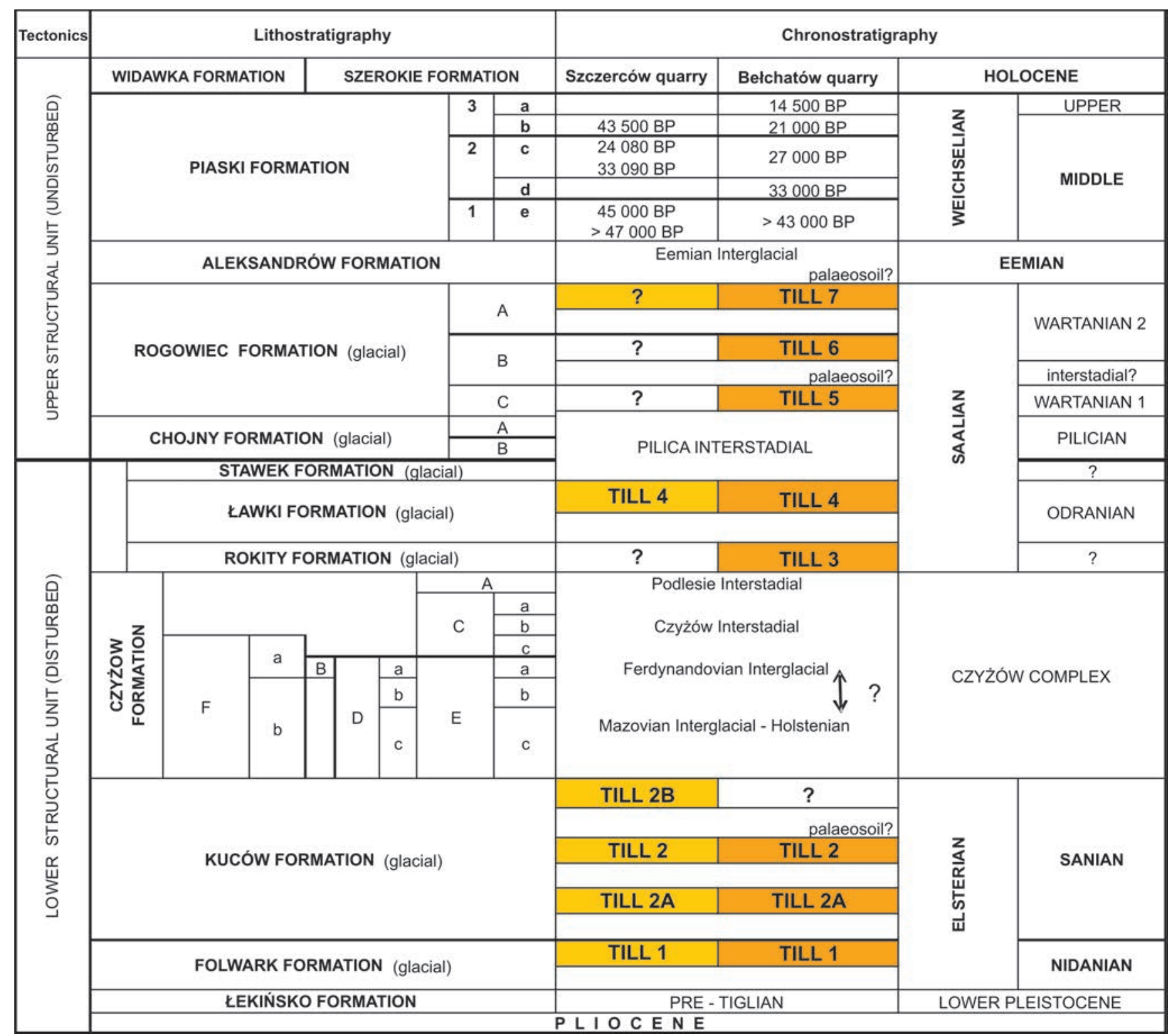

pieces) was divided into two groups. The first group included northern rocks from Scandinavia. The second one consisted of local rocks from lowland areas and those from near the Kleszczów Graben.

Petrographic coefficients $\mathrm{O} / \mathrm{K}, \mathrm{K} / \mathrm{W}$ and $\mathrm{A} / \mathrm{B}$ have been determined according to the assumptions by Gronkowska et al. (1968):

$\mathrm{O}-$ total of sedimentary rocks $[\mathrm{LPl}+\mathrm{D}+\mathrm{S}+\mathrm{Sh}]$;

$\mathrm{K}$ - total of crystalline rocks [Cr+Q];

$\mathrm{W}-$ total of carbonate rocks $[\mathrm{LPl}+\mathrm{D}]$;

$\mathrm{A}-$ total of non-resistant rocks $[\mathrm{LPl}+\mathrm{D}+\mathrm{Sh}]$;

$\mathrm{B}-$ total of resistant rocks $[\mathrm{Cr}+\mathrm{Q}+\mathrm{S}]$.

For full interpretation of petrographic coefficients of tills, the D/LPl ratio is also used that relates the amount of dolomite to limestone clasts in the carbonate group (see Czerwonka, 1998; Krzyszkowski, 2010b). The results are pre- sented in figures 4 and 5. Determinations of tills are adopted from Czerwonka and Krzyszkowski (1992) and from Wachecka-Kotkowska et al. (2014).

Similar research methods have been used across Europe (see Ehlers et al., 1984; Böse, 1989; Panzig, 1992; Albrecht, 1995; Andreicheva, 2012).

\section{RESULTS}

The first observations of the quarry wall in the Szczerców outcrop were made by Król et al. (2007) and provided the basis for the description of a few till beds (see Table 3): G1 (referred to the Nidanian or Sanian Glaciation), G1/2 (Sanian or Odranian Glaciation), G2/1 (Odranian Glaciation older till or Sanian Glaciation younger till), G2 (Odranian Glaciation) and G3 (Wartanian Glaciation). Attention was 
Table 2 Petrographical types of rocks distinguished in the study, and their symbols

\begin{tabular}{|c|l|c|l|}
\hline \multicolumn{2}{|c|}{ Northern, Scandinavian rocks } & \multicolumn{2}{|c|}{ Local rocks } \\
\hline Symbols & Petrographic type of rock & Symbols & Petrographic type of rock \\
\hline Cr & $\begin{array}{l}\text { Crystalline (including } \\
\text { schists) }\end{array}$ & L/M & Limestones and marls \\
\hline Q & Quartz & S & Sandstones \\
\hline LPl & $\begin{array}{l}\text { Lower Palaeozoic lime- } \\
\text { stones }\end{array}$ & M1 & $\begin{array}{l}\text { Palaeogene 'older' } \\
\text { mudstones }\end{array}$ \\
\hline D & Dolomite & M2 & $\begin{array}{l}\text { Neogene 'younger' } \\
\text { mudstones }\end{array}$ \\
\hline S/Qt & $\begin{array}{l}\text { Sandstones and } \\
\text { quartzites }\end{array}$ & Q & Quartz \\
\hline Sh/Ps & Shales/Palaeozoic slates & F1 & Flints \\
\hline & & H & Hornstones \\
\hline & & F & Phosphatic concretions \\
\hline & & Pt & Pyrite concretions \\
\hline & & C & Lignite/brown coal \\
\hline
\end{tabular}

paid to a strong deformation of these tills (Fig. 2). The stratigraphic positions of tills G3 and G2 are relatively reliable; less reliable is that of the till G1. These authors claim that the petrographic coefficients of the till G1 (0.91-1.27-0.70; D/LPl 0.16) are similar of the lower horizon of the Kucówtype till (Fig. 4; Table 3), and the petrographic coefficients of the till G2 $(0.54 \div 0.81-1.43 \div 2.19-0.42 \div 0.63 \mathrm{D} / \mathrm{LPl} 0.05 \div$ $0.07)$ are typical for the Ławki-type till. Similar amounts of crystalline rocks and northern limestones are observed at the top of the till G2 (1.23-0.86-1.10; D/LP1 0.05). The youngest till lithotype, G3, is characterized by the following coef- ficients: $1.52-0.71-1.32$ and D/LP1 0.18 (Rogowiec till). The studies also recognized other till lithotypes, however with unclear geological setting. Their petrographic coefficients are as follows: $1.61-0.65-1.42$ and D/LPl 0.14. It suggests the youngest glacial episode of the South Polish Complex. The coefficient values of 1.51-0.69-1.35 and D/LP1 0.16 point to the possibility of incorporating the South Polish tills into the sediments of the Middle Polish Complex and the values $1.12-0.95-0.99$ and D/LPl 0.21 indicate the middle lithotype of tills, coming probably from the South Polish Complex.

Reinterpretation of the data of Sarnacka (1971) and of archival borehole sections, performed by Wieczorek and Stoiński (2013), provided a basis for the identification of four glacial tills corresponding to the following stratigraphic till beds: Nidanian Glaciation and Sanian 1 Glaciation (within the South Polish Complex), Odranian Glaciation and Wartanian Glaciation (within the Middle Polish Complex) (Table 3). Those studies also included new investigations of tills (Dobosz, 2012) exposed in the Szczerców outcrop - in the east wall near Parchliny and the Krasówka valley (Figs 1 and 2). Examinations of samples collected from the lowest till bed, overlying the Neogene deposits (clay-sand complex), suggested the lithotype T2 in the Kuców Formation (Sanian Glaciation): 1.29-0.86-1.08 and D/LPl 0.15 (Table 3). Slightly different coefficient values were obtained for samples from the upper till: $1.38-0.83-1.05$ and D/LP1 0.23. This petro- graphic pattern may result either from a change in ice movement direction or can suggest presence of a separate glacial bed corresponding to the South Polish Complex. For the purpose of the map construction, it has been assumed that these tills are also of the Sanian 1 age. The overlying tills

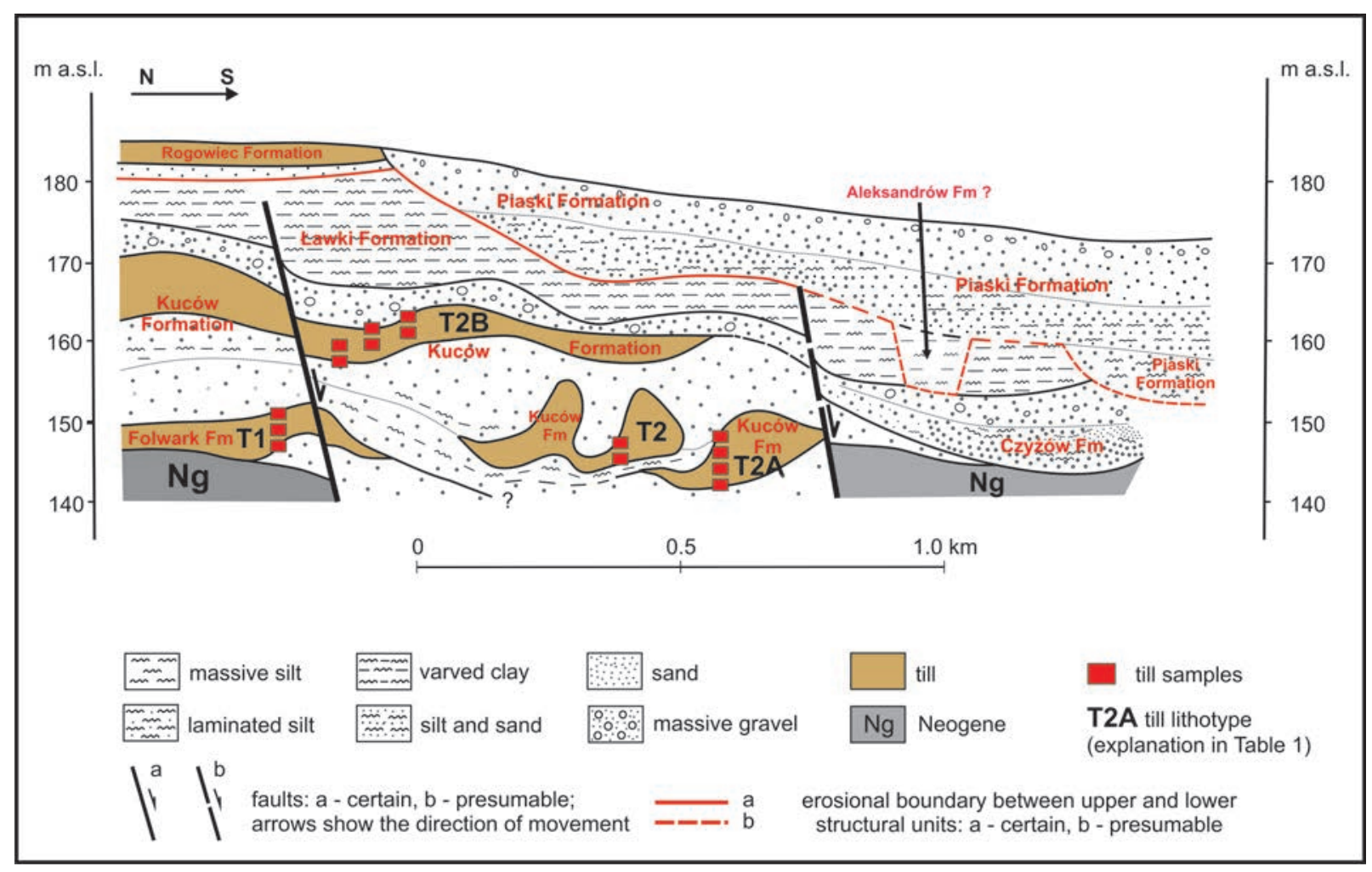

Fig. 2. Geological sketch of Quaternary sediments in the eastern part of the Szczerców outcrop (near Parchliny), April 2012. 
Table 3

Comparison of petrographic coefficients of tills $(\mathrm{O} / \mathrm{K}-\mathrm{K} / \mathrm{W}$ A/B, D/LPl) from the Szczerców region and Szczerców outcrop

\begin{tabular}{|c|c|c|c|c|c|}
\hline Sarnacka (1970) & Król et al. (2007) & $\begin{array}{l}\text { Dobosz (2012), } \\
\text { Wieczorek and } \\
\text { Stoiński (2013) }\end{array}$ & $\begin{array}{c}\text { Wachecka- } \\
\text { Kotkowska et al. } \\
(2013,2014)\end{array}$ & & $\begin{array}{l}\text { rati- } \\
\text { aphy }\end{array}$ \\
\hline $\mathbf{Q}^{2} \mathbf{p}_{3}$ & $\begin{array}{c}\text { G3 } \\
\text { (Rogowiec till) } \\
1.52-0.71-1.32 \\
\mathrm{O} / \mathrm{K}-\mathrm{K} / \mathrm{W}-\mathrm{A} / \mathrm{B} \\
\\
\mathrm{D} / \mathrm{LPl}=0.18\end{array}$ & $\begin{array}{c}1.65-0.64-1.42 \\
\mathrm{O} / \mathrm{K}-\mathrm{K} / \mathrm{W}-\mathrm{A} / \mathrm{B} \\
\mathrm{D} / \mathrm{LPl}=0.19\end{array}$ & -- & 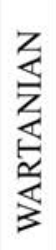 & 苛 \\
\hline $\begin{array}{c}\mathbf{Q}^{1} \mathbf{p}_{3} \\
0.97-1.24-0.72 \\
\mathrm{O} / \mathrm{K}-\mathrm{K} / \mathrm{W}-\mathrm{A} / \mathrm{B}\end{array}$ & $\begin{array}{c}\mathbf{G 2} \\
\text { (Lawki till) } \\
1.23-0.86-1.10 \\
\mathrm{O} / \mathrm{K}-\mathrm{K} / \mathrm{W}-\mathrm{A} / \mathrm{B} \\
\mathrm{D} / \mathrm{LPl}=0.05 \\
\mathbf{G 2} \\
\text { (Lawki-type till) } \\
0.54 \div 0.81-1.43 \div 2.19-0.42 \div 0.63 \\
\mathrm{O} / \mathrm{K}-\mathrm{K} / \mathrm{W}-\mathrm{A} / \mathrm{B} \\
\mathrm{D} / \mathrm{LPl}=0.05 \div 0.07 \\
\end{array}$ & 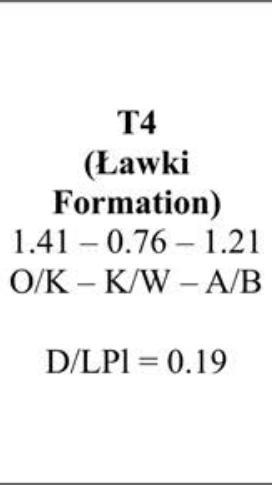 & $\begin{array}{c}\text { T4 } \\
\text { (Lawki Formation) } \\
0.98-1.32-0.75 \\
\text { O/K }-\mathrm{K} / \mathrm{W}-\mathrm{A} / \mathrm{B} \\
\mathrm{D} / \mathrm{LPl}=0.17\end{array}$ & 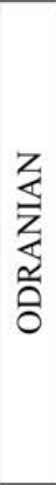 & 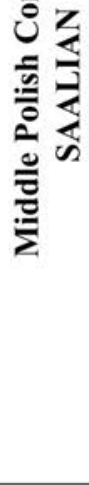 \\
\hline \multirow[b]{2}{*}{$\begin{array}{c}\mathbf{Q}^{2} \mathbf{p}_{2} \\
1.05 \div 1.13- \\
1.05 \div 1.17- \\
0.75 \div 0.89 \\
\mathrm{O} / \mathrm{K}- \\
\mathrm{K} / \mathrm{W}- \\
\mathrm{A} / \mathrm{B}\end{array}$} & $\begin{array}{c}1.61-0.65-1.42 \\
\mathrm{O} / \mathrm{K}-\mathrm{K} / \mathrm{W}-\mathrm{A} / \mathrm{B} \\
\mathrm{D} / \mathrm{LPl}=0.14 \\
1.12-0.95-0.99 \\
\mathrm{O} / \mathrm{K}-\mathrm{K} / \mathrm{W}-\mathrm{A} / \mathrm{B} \\
\mathrm{D} / \mathrm{LPl}=0.21\end{array}$ & $\begin{array}{c}1.38-0.83-1.05 \\
\mathrm{O} / \mathrm{K}-\mathrm{K} / \mathrm{W}-\mathrm{A} / \mathrm{B} \\
\mathrm{D} / \mathrm{LPl}=0.23\end{array}$ & $\begin{array}{c}\text { T2B } \\
\text { (Kuców } \\
\text { Formation) } \\
1.65-0.64-1.42 \\
\mathrm{O} / \mathrm{K}-\mathrm{K} / \mathrm{W}-\mathrm{A} / \mathrm{B} \\
\mathrm{D} / \mathrm{LPl}=0.19\end{array}$ & & \multirow{3}{*}{ 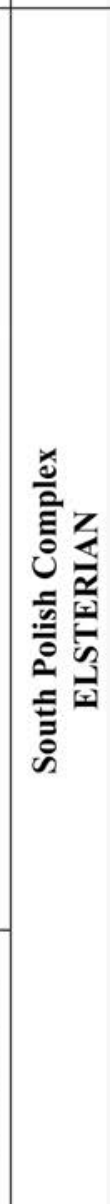 } \\
\hline & $\begin{array}{c}\text { G1 } \\
\text { (lower Kuców-type till?) } \\
0.91-1.27-0.70 \\
\mathrm{O} / \mathrm{K}-\mathrm{K} / \mathrm{W}-\mathrm{A} / \mathrm{B} \\
\\
\mathrm{D} / \mathrm{LPl}=0.16\end{array}$ & $\begin{array}{c}\text { T2 } \\
\text { (Kuców } \\
\text { Formation) } \\
1.29-0.86-1.08 \\
\mathrm{O} / \mathrm{K}-\mathrm{K} / \mathrm{W}-\mathrm{A} / \mathrm{B} \\
\mathrm{D} / \mathrm{LPl}=0.15\end{array}$ & $\begin{array}{c}\text { T2 } \\
\text { (Kuców } \\
\text { Formation) } \\
1.41-0.76-1.21 \\
\mathrm{O} / \mathrm{K}-\mathrm{K} / \mathrm{W}-\mathrm{A} / \mathrm{B} \\
\mathrm{D} / \mathrm{LPl}=0.19 \\
\text { T2A } \\
\text { (Kuców } \\
\text { Formation) } \\
1.38-0.83-1.05 \\
\mathrm{O} / \mathrm{K}-\mathrm{K} / \mathrm{W}-\mathrm{A} / \mathrm{B} \\
\mathrm{D} / \mathrm{LPl}=0.24\end{array}$ & 孞 & \\
\hline $\mathbf{Q}^{1} \mathbf{p}_{2}$ & --- & --- & $\begin{array}{c}\text { T1 } \\
\text { (Folwark } \\
\text { Formation) } \\
1.29-0.86-1.08 \\
\mathrm{O} / \mathrm{K}-\mathrm{K} / \mathrm{W}-\mathrm{A} / \mathrm{B} \\
\mathrm{D} / \mathrm{LPl}=0.15\end{array}$ & $\begin{array}{l}\text { Z } \\
\text { Z } \\
\text { 衣 } \\
\text { Z }\end{array}$ & \\
\hline
\end{tabular}

from the quarry wall is correlated by Dobosz (2012) with the lithotype T4 of the Lawki Formation (Odranian Glaciation). They are characterized by the following coefficients: $1.41-$ 0.76-1.21 and D/LP1 0.19. The petrographic coefficients of the uppermost tills in the section are as follows: $1.65-0.64$ 1.42 , D/LPl 0.19 and the tills are correlated with the Wartanian cold stage (see Fig. 4; Table 3).

Analysis of the results obtained by Dobosz (2012), in 

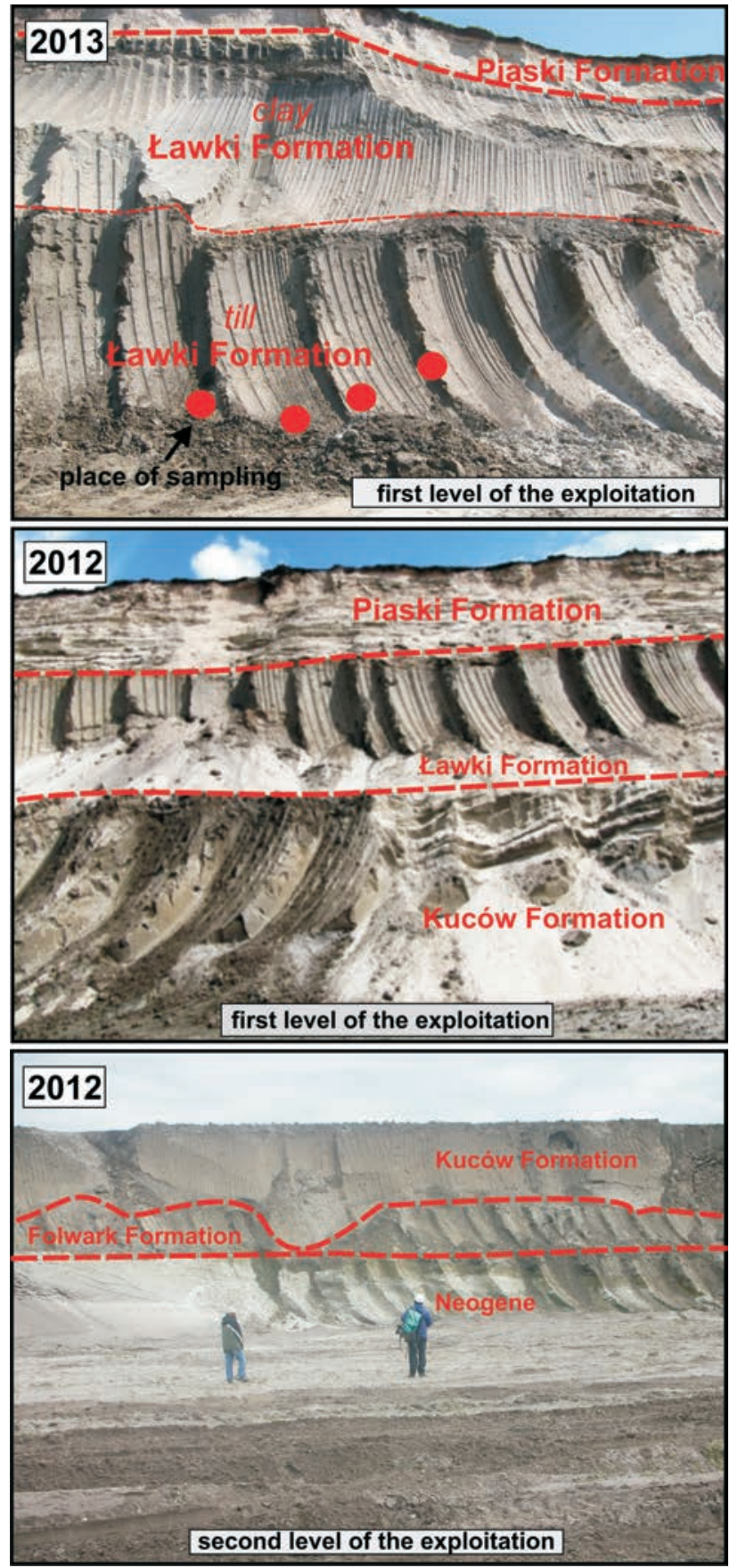

Fig. 3. Photos documenting the eastern part of the Szczerców outcrop in April 2012 and May 2013 (sampling sites).

combination with other data (see Wachecka-Kotkowska et al., 2013), provoked a discussion on possible different stratigraphic interpretation of the tills examined in 2012 (Fig. 3). As a result, a concept arose that the tills observed in the section represent the South Polish Complex only, correlated with the Folwark (T1) and the Kuców formations (T2A, T2 and T2B) (see Wieczorek et al., in press). A new till lithotype T2B $1.65-0.64-1.42$ was also determined (see Fig. 4; Table 3 ). The value of D/LPl coefficient (0.19) is the same as for T2, but all ratios $\mathrm{O} / \mathrm{K}-\mathrm{K} / \mathrm{W}-\mathrm{A} / \mathrm{B}$ for $\mathrm{T} 2 \mathrm{~B}$ are about $0.1-0.2$ higher than for T2 (1.41-0.76-1.21).
In the tills of the Folwark Formation (T1), crystalline rocks are more poorly represented than carbonate rocks. The $\mathrm{CaCO}_{3}$ content in this layer is about 5\%. Local rocks account for a considerable proportion $(\sim 25-30 \%)$. The value of $\mathrm{D} / \mathrm{LPl}$ coefficient is approximately 0.15 .

Till beds - T2A, T2, T2B - located in the upper part of the section (Fig. 2) within the Kuców Formation are characterized by similar $\mathrm{K} / \mathrm{W}$ coefficient values as in the case of the till T1 (Fig. 4; Table 3). In the till T2A, the amount of local rocks is larger $(\sim 30-40 \%)$ than in the till $\mathrm{T} 1$, however the succeeding beds have lower contents of local rocks (T2 $\sim 20 \%$; T2B $<10 \%$ ). The values of coefficient $\mathrm{D} / \mathrm{LPl}$ vary in these tills from $\sim 0.24$ to $\sim 0.19$. A succession of tills from the Kuców Formation indicates an increased $\mathrm{CaCO}_{3}$ content from about $5 \%$ to approximately $10 \%$ (Fig. 4). The variability of individual data may indicate growing isolation of the successive ice sheets from the basement. Similar characteristics of petrographic coefficients of the T2A, T2 and T2B tills confirm probably their affiliation to a single formation and can indicate environmental changes, that is a change in the ice sheet movement direction and actually of its individual lobes (see Krzyszkowski, 2010b).

In 2013, several new till samples were taken from the first mining level of the Szczerców outcrop (Fig. 3). The eastern wall was located 250-300 m more eastwards than in 2012. Results of petrographic studies of these tills indicate that they represent the Ławki Formation, lithotype T4: 0.98$1.32-0.75$ and D/LPl is 0.17 (Fig. 4). These coefficients correspond well to those of the Smolna-type tills from the Silesian Lowland, correlated with the Odranian (see Czerwonka and Krzyszkowski, 1992; Czerwonka et al., 1998). Setting of this till is thus a good reference point.

In the till of the Lawki Formation (T4), crystalline rocks predominate over carbonates. Resistant rocks also predominate (Fig. 4; Table 3). A graphic image of the petrographic coefficients is different from that of the tills of older formations. This till has a very high content of carbonates, up to $\sim 28 \%$. Compared to tills T2B and T2 of the Kuców Formation, it contains more local rocks. This till bed is clearly different from the older tills.

\section{DISCUSSION}

Petrographic coefficients of tills from the South Polish Complex, obtained during the present research, differ from those reported in previous years (see Czerwonka et al., 1998; Krzyszkowski, 2010a).

There are problems with their stratigraphic interpretation. Differences in the coefficient values for tills T2, T2A and T2B may result from their incorrect identification, from variations in the petrographic composition within the same till or from various oscillations of the same ice sheet. The petrographic determinations were made by an expert with many years' experience and analysed all samples from the Bełchatów and Szczerców outcrops. Hence, the first option should be rejected. Although petrographic variability within the same till is possible, but the presence of intervening lag layers between tills T2A, T2 and T2B also excludes such option (Fig. 2). Thus, it is most likely that tills T2A, T2 and T2B represent successive stages of the same glaciation. 


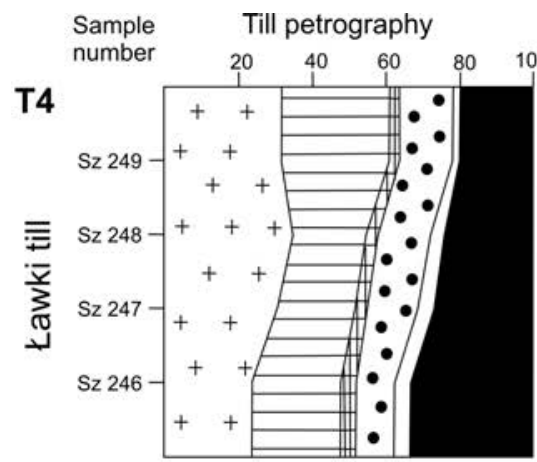

Petrographic
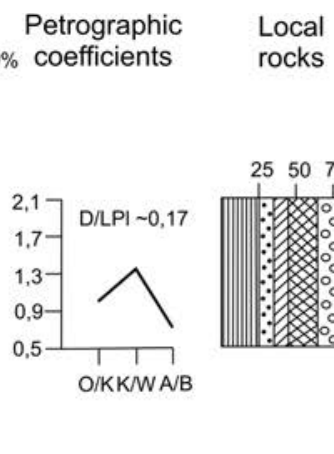

rocks
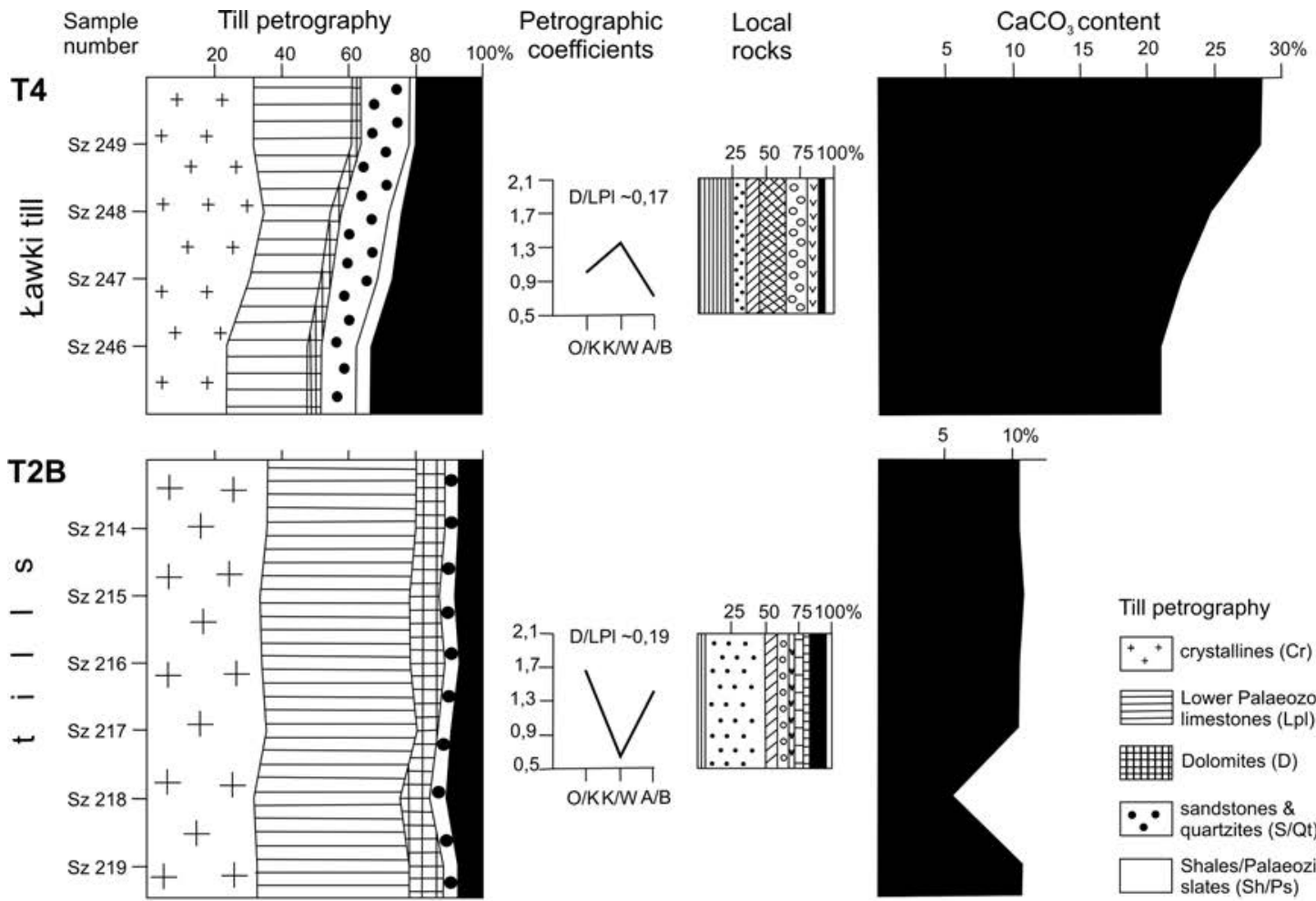

T2
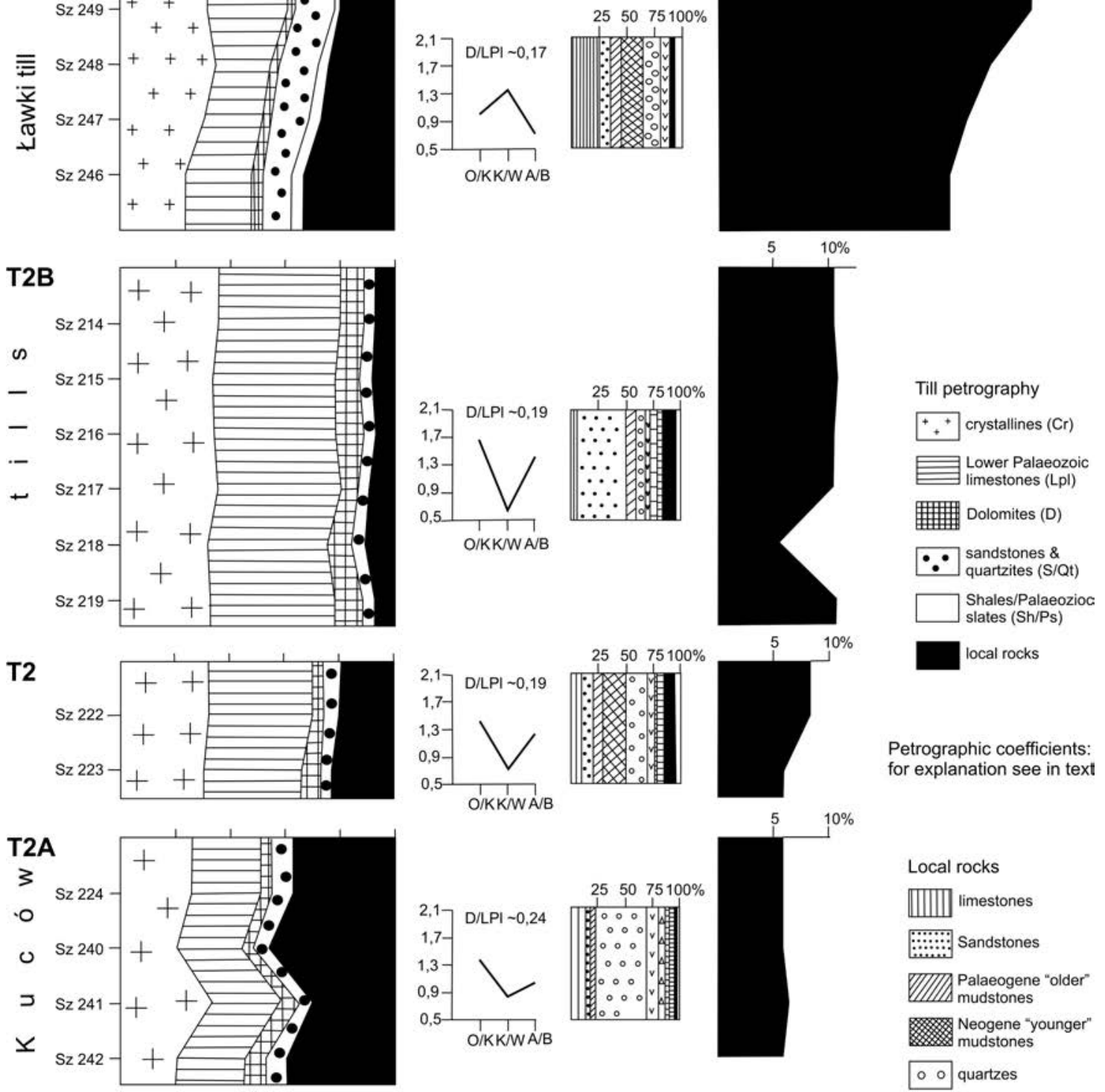

Till petrography

$+_{+}^{+}$crystallines (Cr)

Lower Palaeozoic
limestones (LPI)

姍曲 Dolomites (D)

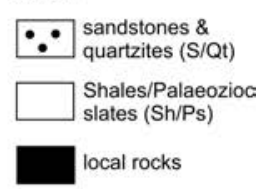

Petrographic coefficients: for explanation see in text
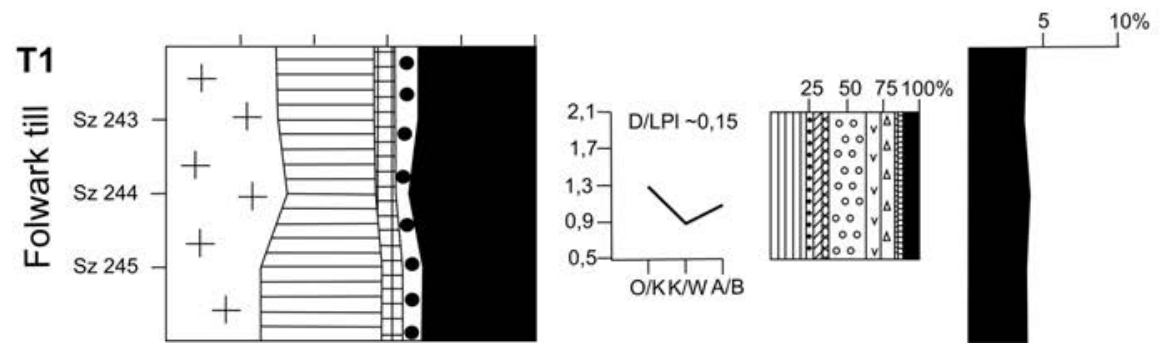

$v^{v}$ f flints

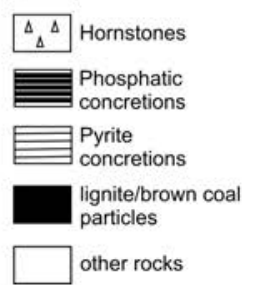

Fig. 4. Petrographic features of tills in the Szczerców outcrop after Wachecka-Kotkowska et al. (2014), modified.

Till beds were deposited during main glaciations - each glaciation contains a till or several tills from different stadials. The glacial tills correlation, based on gravel petrography, indicates that each of them can be characterized by different (or similar) gravel assemblages (see Czerwonka, 1998; Czerwonka and Krzyszkowski, 1990, 1992; Czerwonka et al., 1998). There are also situations that the age-equivalent tills indicate quite a different petrographic composition. Differ- entiation of petrographic coefficients may suggest deposition of age-equivalent tills by different glacial lobes. There are examples of studies on different Scandinavian ice sheet flows and theories about ice streams (Boulton et al., 2001; Bennett, 2003; Kalm, 2012; Kalm and Gorlach, 2014). An interpretation of palaeogeographic distribution of ice lobes in Poland and of glacial palaeotransport during the South Polish Complex, Elsterian, is presented (Fig. 5). The dissimilarity of 

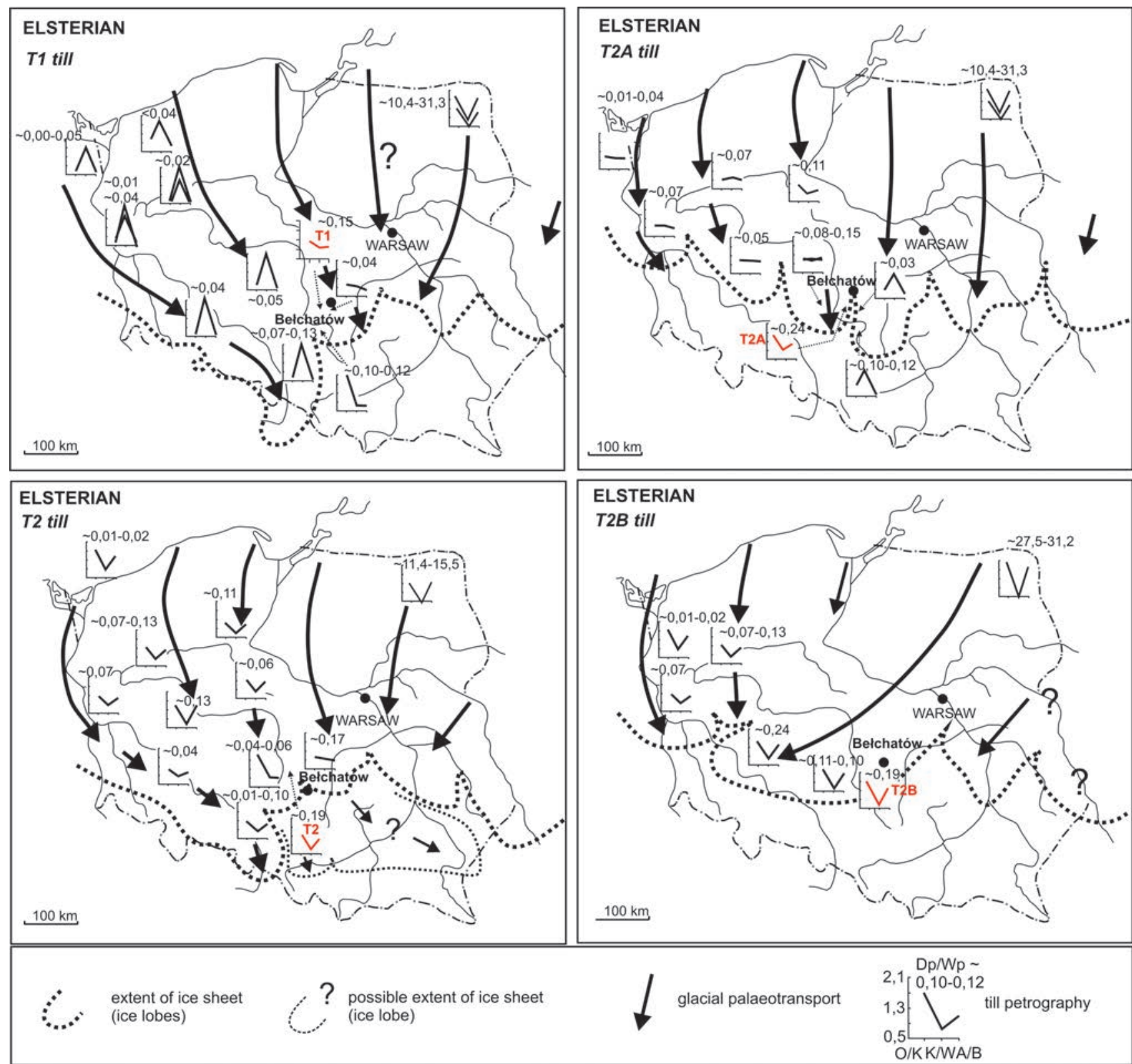

Fig. 5. Interpretation of palaeogeographic distribution of ice lobes and glacial palaeotransport during the South Polish Complex.

these coefficients can be also explained by local variation of sedimentary processes taking place under the base of the ice sheet.

In the Szczerców vicinity, the till marked as T1 of the Folwark Formation (Nidanian Glaciation of the South Polish Complex) has intermediate values of petrographic coefficients between western and eastern Poland. It suggests that the ice sheet of this glaciation had well-developed lobes. General glacial palaeotransport was from the north (Fig. 5).

The most congruent coefficient is that of the till T2, corresponding quite well to the Wierzbno-type tills in the Silesian Lowland (see Czerwonka et al., 1998). Setting of this till may be another reference point. The authors are of the opinion that the diversity of these coefficients results from a type of ice sheet advance, comprising a series of lobes (see Krzyszkowski, 2010b), with the predominant westerly direction (Fig. 5).
Based on earlier studies (see Krzyszkowski 2010b) we can say more on the tills marked as T2A and T2, and also about the new till marked as T2B. These tills have been assigned to the Kuców Formation (they represent Sanian 1 and Sanian 2 glaciations - see Table 1).

Initially, glacial palaeotransport was from the north (T2A) and as previously, there were ice sheet lobes. Similar petrographic coefficients are observed in western Poland. During the younger glacial period (T2) the lobes were of differentiated dynamics - the western lobes advanced to their maximum extent earlier than the eastern ones (Fig. 5). An area free of intra-ice "oasis" could have existed between the Odra and Warta-Prosna lobes. Glacial palaeotransport was from the north and north-east. The values of petrographic coefficients are also similar to those in western Poland, but different than for T2A. In the late phase of the glaciation (T2B), during general recession of the western lobes, the eastern 
lobes were more active and increased their extents by $100-250 \mathrm{~km}$. Direction of glacial palaeotransport was more from the north-east. The values of petrographic coefficients are similar at all sites in Poland.

\section{CONCLUSIONS}

The petrographic studies of tills in the Szczerców outcrop, central Poland, confirm the occurrence of tills T1 (Folwark Formation, Nidanian), T2, T2A (Kuców Formation, Sanian) and T4 (Ławki Formation, Odranian). A new till lithotype, T2B, is described in this paper.

There is a question where to locate the till T2B in terms of lithostratigraphy. Taking into account the values of petrographic coefficients of the tills T2A, T2 and T2B, they have been assigned to the Kuców Formation. In the analysed section, the till T2B overlies the tills T2 and T2A. It can be considered a separate till, resulting from either oscillations of the marginal part of the ice sheet or a different ice-movement direction. This till can correspond to the Sanian 2 Glaciation (see Krzyszkowski, 2010b).

In the eastern part of the Kleszczów Graben, the Wartanian till complex (Rogowiec Formation) is represented by three separate tills: T5, T6 and T7. In the western part, it seems to be reduced to a single till (T7?) that occurs in the graben margins only (see Table 1). The older tills occur in the western part of the graben where they are represented by three beds: T2A, T2 and T2B (Kuców Formation, Sanian). In the eastern part, there is mainly T2 and locally also T2A. The question about the rank and the number of South Polish ice sheet advances (South Glacial Complex, sensu Lindner et al., 2013) in central Poland still remains open and requires further research.

The research results of the tills and their lithostratigraphic interpretation, presented in this paper, should be treated as preliminary ones. The issue requires further studies, and the authors express hope that it will be possible as the process of overburden removal in the Szczerców outcrop advances.

\section{Acknowledgements}

The authors thank the Directorate of the KWB Bełchatów Lignite Mine, which is part of the PGE Mining and Conventional Energy Company, for making them the opportunity to carry out research of the Quaternary deposits in the Szczerców outcrop. Thanks are also given to a geologist Anna Skórzak, MSc, for organizational assistance. Part of the research was carried out during the updating of the Szczerców Sheet (735) of the DGMP, scale 1:50,000. The work was performed to the order of the Minister of the Environment, and financed by the National Fund for Environmental Protection and Water Management.

\section{REFERENCES}

Albrecht, J., 1995. Moränstratigrafi och glacial dynamic i NO Tyskland under Weichsel. Problemanalys. Dept. of Quart. Geol., Lund University.

Allen, P., Krzyszkowski, D., 2008. Till base deformation and fabric variation in lower Rogowiec (Wartanian, younger Saalian) till, Bełchatów outcrop, central Poland. Annales Societatis Geologorum Poloniae 78, 19-35.

Andreicheva, L.N., 2012. Lithology of Upper-Middle Pleistocene tills in the far northeast of European Russia. Lithology and
Mineral Resources 47 (3), 253-263.

Bennett, M.R., 2003. Ice streams as the arteries of an ice sheet: their mechanics, stability and significance. Earth-Science Reviews 61, 309-339.

Boulton, G.S., Dongelmans, P., Punkari, M., Broadgate, M., 2001. Palaeoglaciology of an ice sheet through a glacial cycle: the European ice sheet through the Weichselian. Quaternary Science Reviews 20, 591-625.

Böse, M., 1989. Methodisch-stratigraphische Studien und paläomorphologische Untersuchungen zum Pleistozän südlich der Ostsee. Berliner Geogr. Abhandlungen, 51.

Czerwonka, J.A., 1998. Litostratygrafia glin lodowcowych: uwagi metodyczne. Biuletyn Państwowego Instytutu Geologicznego 385, 113-125 (in Polish with English summary).

Czerwonka, J.A., Krzyszkowski, D., 1990. Saalian Tills in the Bełchatów Outcrop, Central Poland. Bulletin of the Polish Academy of Sciences, Earth Sciences 38, 63-75.

Czerwonka, J.A., Krzyszkowski, D., 1992. Till characteristics and stratigraphy in the Kleszczów Graben (Central Poland). Quaternary Studies in Poland 11, 43-64.

Czerwonka, J.A., Dobosz, T., Haisig, J., Krzyszkowski, D., Wilanowski, S., 1998. Stratygrafia i petrografia glin lodowcowych w międzyrzeczu Odry i Warty, Polska południowo-zachodnia). Biuletyn Państwowego Instytutu Geologicznego 385, 73-104.

Dobosz, T., 2012. Badania mineralogiczno-petrograficzne osadów plejstoceńskich z Odkrywki w Szczercowie dla potrzeb reambulacji ark. Szczerców (735) SMGP w skali 1: 50000. Centralne Archiwum Geologiczne PIG-PIB, Warszawa, 1-12.

Ehlers, J., Meyer, K.D., Stephan, H.J., 1984. Pre-Weichselian European Pleistocene ice sheets, Quaternary Science Reviews 3, $1-40$.

Ehlers, J., Gibbard, P., 2008. Extent and chronology of Quaternary glaciation. Episodes 31 (2), 211-218.

Gronkowska, B., Kenig, K., Rzechowski, J., 1968. Petrografia glin zwałowych Podlasia i Mazowsza. Archiwum PIG, Warszawa.

Kalm, V., 2012. Ice-flow pattern and extent of the last Scandinavian Ice Sheet southeast of the Baltic Sea. Quaternary Science Reviews 44, 51-59.

Kalm, V., Gorlach, A., 2014. Impact of bedrock surface topography on spatial distribution of Quaternary sediments and on the flow pattern of late Weichselian glaciers on the East European Craton (Russian Plain). Geomorphology 207, 1-9.

Król, J., Hałuszczak, A., Dobosz, T., 2007. Dokumentowanie profili geologicznych z odsłonięć KWB Bełchatów i KWB Konin etap I (obejmujący część pilotażową). I Rejon KWB Bełchatów, odkrywka Szczerców. Centralne Archiwum Geologiczne PIG-PIB, Warszawa, 1-86.

Krzyszkowski, D. 1988. The Rogowiec Formation in a Kleszczów Graben, a New View for the Wartanian (Warthe) Glaciation in Central Poland. Bulletin of the Polish Academy of Sciences, Earth Sciences 36, 287-298.

Krzyszkowski, D. 1992. Czwartorzęd Rowu Kleszczowa: litostratygrafia i tektonika. Zarys problematyki na podstawie obserwacji w odkrywce KWB Bełchatów. Acta Universitatis Wratislaviensis No 1252, Studia Geograficzne 54, 1-158.

Krzyszkowski, D., 2010a. Stratygrafia glin lodowcowych w zachodniej Polsce - dyskusja. In: Marks, L., Pochocka-Szwarc, K. (Eds), XVII Konferencja Stratygrafia plejstocenu Polski Dynamika zaniku ladolodu podczas fazy pomorskiej w pótnocno-wschodniej części Pojezierza Mazurskiego. Jeziorowskie, 6-10.09.2010 PIG-PIB, Warszawa, 123-127.

Krzyszkowski, D., 2010b. The first record of red till lithotype in Western Poland and its implication for glacial stratigraphy and palaeogeography. Annales Societatis Geologorum Poloniae $80,53-67$. 
Lindner, L., Marks, L., Nita, M., 2013. Climatostratigraphy of interglacials in Poland: Middle and Upper Pleistocene lower boundaries from a Polish perspective. Quaternary International 292, 113-123. dx.doi.org/10.1016/j.quaint.2012.11.018.

Marks, L., 2011. Quaternary Glaciations in Poland. Developments in Quaternary Science 15, 299-303.

Marks, L., Ber, A. (Eds), 1999. Metodyka opracowania Szczegółowej Mapy Geologicznej Polski w skali 1:50 000. PIG, Warszawa.

Panzig, W.A., 1992. The gravel-compositorial standard-profile of the till-inventory of NE Rügen, southwestern Baltic, GDR. Quaestiones Geographicae 3, 143-154.

Sarnacka, Z., 1970. Objaśnienia do Szczegółowej mapy geologicznej Polski w skali 1:50 000, arkusz Szczerców (M34-27A). Wydawnictwa Geologiczne, Warszawa.

Sarnacka, Z., 1971. Szczegółowa mapa geologiczna Polski w skali 1:50 000, arkusz Szczerców (M34-27A). Wydawnictwa Geologiczne, Warszawa.

Wachecka-Kotkowska, L., Krzyszkowski, D., Krzymińska, J., Drzewicki, W., Wieczorek, D., Stoiński, A., 2013. Geneza, litologia i stratygrafia osadów czwartorzędowych rowu Kleszczowa w świetle nowych badań w odkrywce Szczerców. In: A.
Kostrzewski, G. Rachlewicz, M. Woszczyk (Eds), VI Seminarium Geneza, litologia i stratygrafia utworów czwartorzędowych: Poznań, 14-15 listopada 2013, 168-172.

Wachecka-Kotkowska, L., Krzyszkowski, D., Wieczorek, D., Stoiński, A., 2014. Głos w dyskusji nad stratygrafią glin zwałowych w odkrywce Szczerców. In: XXI Konferencja Stratygrafia Plejstocenu Polski Dynamika ladolodów plejstoceńskich na obszarze Sokólszczyzny i Równiny Augustowskiej. Augustów, 1-5 września 2014, 113-115.

Wieczorek, D., Stoiński, A., 2013. Objaśnienia do Szczegółowej mapy geologicznej Polski w skali 1:50 000, ark. Szczerców (735). Centralne Archiwum Geologiczne, PIG-PIB, Warszawa.

Wieczorek, D., Stoiński, A., Krzyszkowski, D., Wachecka-Kotkowska, L., Krzymińska, J., in press. The results of new studies of Quaternary sediments in the Kleszczów Graben, Szczerców Outcrop, Bełchatów Lignite Opencast Mine. Landform Analysis.

Zagwijn, W.H., 1996. The Cromerian Complex Stage of the Netherlands and correlation with other areas in Europe. In: Turner, Ch., (Ed.), The Early Middle Pleistocene in Europe. Balkema, Rotterdam: 145-172. 